\title{
EDITORIAL
}

\section{Sixty years (1954-2014) of José Leme Lopes's fundamental book: As dimensões do diagnóstico psiquiátrico}

\author{
Antonio E. Nardi \\ Editor-in-Chief, Revista Brasileira de Psiquiatria, Panic \& Respiration Laboratory, Institute of Psychiatry, Universidade Federal do Rio de \\ Janeiro (UFRJ), Rio de Janeiro, RJ, Brazil. National Science and Technology Institute for Translational Medicine (INCT-TM), Conselho \\ Nacional de Desenvolvimento Científico e Tecnológico (CNPq), Brazil.
}

At a time when psychiatric diagnosis is again being questioned as to its validity and to the harm it might cause when improperly used, ${ }^{1}$ we must turn our attention to the pillars of diagnostic precision. Among the various psychiatric researchers that emerged in the 20th century dealing with the medical model, José Leme Lopes (19041990) stands out for his fundamental work. His important scientific contribution was the main subject of his 1954 thesis, published as a book in the same year (Figure 1): The dimensions of psychiatric diagnosis (contribution to its systematization). ${ }^{2}$ At the time, his idea of psychiatric diagnosis was a new multi-axial conception, which would earn him a well-deserved homage and broad recognition abroad for the role it would play in the formulation of new nosological classifications suggested by the World Health Organization and by the American Psychiatric Association. The important contribution of this book was further recognized internationally when its original cover page was reproduced in the 6th edition of Kaplan \& Sadock's Comprehensive textbook of psychiatry. ${ }^{3}$ Leme Lopes fought for a scientific psychiatry with ties to medicine and taking into account the contribution of other aspects of human thought.

In his book, Leme Lopes presented the difficulties in precise psychiatric diagnosis as a main problem of our clinical and research practice. Diagnosis is the fundamental process in all medical practice, and psychiatry could not be different. The dimensions of psychiatric diagnosis was republished and updated in $1980 .{ }^{4}$ In this edition, the book has 10 chapters, only the first five of which belonged to the original edition. The original five chapters are: "The vicissitudes of psychiatric diagnosis"; "The dissolution of the diagnosis"; "The reconstruction of the diagnosis"; "The development of the diagnostic problem"; and "Diagnosis nowadays." The updated edition had five more chapters: "The diagnostic evaluation"; "Standard diagnostic interviews"; "The diagnostic dimensions and the dynamic pluridimensional diagnosis"; "The diagnosis procedure"; and "The ICD-9."

Correspondence: Antonio E. Nardi, Laboratory of Panic \& Respiration, Institute of Psychiatry, Universidade Federal do Rio de Janeiro (UFRJ), Rua Visconde de Pirajá, 407/702, CEP 22410003, Rio de Janeiro, RJ, Brazil.

E-mail: antonioenardi@gmail.com
Throughout the book, one can recognize the tremendous psychopathological, philosophical, and scientific background of Leme Lopes. He magnificently mastered each point of the validity of psychiatric diagnosis. The psychiatric interview, the history of symptoms, the psychopathological and physical examinations, the

\section{JOSÉ LEME LOPES}

\section{AS DIMENSÕES DO DIAGNÓSTICO PSIQUIÁTRICO (Contribuição para sua sistematização)}

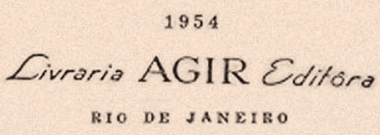

Figure 1 Title page of Leme Lopes's 1954 book As dimensões do diagnóstico psiquiátrico (contribuição para sua sistematização), or The dimensions of psychiatric diagnosis (contribution to its systematization) 
syndrome, the family and personal history, and the laboratory workup were all precisely described in terms of their importance and proper place to achieve the best possible validity. Leme Lopes also emphasized cultural features and long-term follow-up as crucial aspects.

Leme Lopes stands beside other pillars of psychiatric diagnosis research, such as Emil Kraepelin, Kurt Schneider, Adolf Meyer, and Henry Ey. ${ }^{5}$ His contribution to the study of diagnosis must be highlighted whenever its validity is questioned.

\section{Acknowledgements}

This report was supported by Conselho Nacional de Desenvolvimento Científico e Tecnológico (CNPq) and the National Science and Technology Institute for Translational Medicine (INCT-TM).

\section{Disclosure}

The author reports no conflicts of interest.

\section{References}

1 Nardi AE, Kapczinski F, Quevedo J, Hallak JE, Freire R, RomanoSilva MA. The quest for better diagnosis: DSM-5 or RDoC? Rev Bras Psiquiatr. 2013;35:109-10.

2 Leme Lopes J. As dimensões do diagnóstico psiquiátrico (contribuição para sua sistematização). Rio de Janeiro: Agir; 1954.

3 Mezzich JE. International perspectives on psychiatric diagnosis. In: Sadock BJ, Kaplan HI. Comprehensive textbook of psychiatry 6th ed. Baltimore: Williams \& Wilkins; 1995. p. 692-703.

4 Leme Lopes J. Diagnóstico em psiquiatria. Rio de Janeiro: Cultura Médica; 1980.

5 Nardi AE, Hallak JE, Crippa JA. Prof. José Leme Lopes (1904-1990): the pioneer of the multi-axial diagnosis. Arq Neuropsiquiatr. 2010; 68:479-80. 